UDK: 159.944.4:159.923

Izvorni naučni rad

Primljeno: 22.2.2019.

Prihvaćeno za štampu: 31.5.2019.

Arijana Midžić, asistent

Univerzitet u Bihaću

Islamski pedagoški fakultet

ari_jana_91@windowslive.com

\title{
STRATEGIJE SUOČAVANJA SA STRESOM I DIMENZIJE LIČNOSTI
}

\section{Sažetak}

Stres kao obrazac emocionalnih i fizičkih reakcija koje prati osjećaj preopterećenosti $i$ koje nastaju kao reakcija na odredene dogadaje je uobičajen $u$ životima ljudi. Značajan je faktor koji može nepovoljno uticati na svakodnevno funkcionisanje ljudi i kvalitetu njihovih odnosa sa drugima. Stres pojedinci doživljavaju vezano za svoje svakodnevne obaveze. Dosadašnja istraživanja su pokazala da su dimenzije ličnosti značajno povezane sa sterategijama suočavanja sa stresom, te se u posljednje vrijeme ističe i važnost situacije koja djeluje na doživljaj stresa u interakciji sa dimenzijama ličnosti. $U$ ovom radu je napravljena relacija između strategija suočavanja sa stresom $i$ dimenzija ličnosti Petofaktorskog modela (ekstraverzija, prijatnost, savjesnost, neuroticizam $i$ otvorenost $k a$ iskustvu). Postoje različiti modeli/strategije suočavanja sa stresom, a to su: usmjerenost na emocije, usmjerenost na problem i treća strategija suočavanja sa stresom je suočavanje izbjegavanjem, zatim modeli koji opisuju set faktora koji utiču na otpornost na stres $i$ proces po kojem ti faktori funkcioniraju $i$ modeli koji podrazumijevaju da stepen slaganja izmecu osobe i okoline odrecuje kvalitetu otpora prema stresu, teoriju u kojoj otpornost (eng. hardiness) utiče na interpretaciju stresnih životnih dogadaja u određenju tzv. transformacijskog suoćavanja i transakcijski model.

Ključne riječi: stres, strategije suočavanja sa stresom, ličnost, dimenzije ličnosti. 


\section{Uvod}

U današnje vrijeme karakteristika koja definira egzistenciju čovjeka jeste brz tempo života. Svakodnevni problemi i njihovo nerješavanje su izvori stresa. Suočavanja sa međuljudskim odnosima, profesionalnim, privatnim i drugim odnosima dovode do zdravstvenih tegoba pa sve do prerane smrti. Uzroci stresa mogu biti brojni i mogu se interpretirati na mnogo razina. Najpoznatija podjela $u$ tri velike kategorije koje objašnjavaju uzroke stresa kao i važnost uzroka stresa su: intrinzični interes, psihosocijalni modeli adaptacije i biomedicinski modeli adaptacije.

Stres ovisi o osobinama pojedinca koji se nalazi u stresnoj situaciji, kao i o karakteristikama te situacije. Osobine pojedinca određuju što je važno za njegovu dobrobit u određenoj situaciji, oblikuju razumijevanje osobe o samom događaju što, potom, utiče na način na koji će se osoba nositi sa stresnom situacijom. Za načine suočavanja i prevladavanja stresa se smatra da predstavljaju jedan od najznačajnijih izvora individualnih razlika. Načine suočavanja sa stresnom situacijom osoba svjesno odabire ovisno o okolnostima u kojima se nalazi, kao i o tome šta ona inače čini da bi smanjila doživljaj stresa. Pojedine strategije ${ }^{1}$ suočavanja se ne procjenjuju kao univerzalno dobre ili loše, već koliko su primjerene određenoj situaciji. ${ }^{2}$

Pojam stresa izaziva veliku pažnju istraživača kako na teorijskom tako i na metodološkom planu prvenstveno zbog uvjerenja da je uzrok mnogih ljudskih poteškoća. Proces suočavanja sa stresom uključuje odabir različitih strategija na svjesnoj ili nesvjesnoj razini. Koja će strategija biti odabrana, ovisi kako o individualnim razlikama $\mathrm{u}$ dimenzijama ličnosti, spolu i dobi, tako i o karakteristikama stresne situacije i konteksta unutar kojeg se odvija proces suočavanja.

\footnotetext{
1 „Strategija“ dolazi od starogrčke riječi stratēgos i doslovno znači „vođenje vojske“ (grč. Stratos: vojska, ago: voditi, strategos: vojskovođa). Vremenom je izgubljeno to prvobitno značenje i koristi se da bi se označilo postupanje usmjereno ka ostvarivanju određenog cilja nakon dužeg planiranja.

${ }^{2}$ Hudek - Knežević, J. i sar. (2009). Organizacijski stres i stavovi prema radu kao prediktori zdravstvenih ishoda. Prospektivno istraživanje. Društvena istraživanja. Vol.18, Br.1-2, 129-149.
} 
Kada je riječ o definisanju ličnosti, jedna od najčešćih definicija ličnosti kaže da je ličnost skup organiziranih, razmjerno trajnih psiholoških osobina i mehanizama unutar pojedinca koji utiču na njegove interakcije s okolinom i prilagodbu na okolinu. Problem definisanja ličnosti kao psihologijskog konstrukta postoji od početka, odnosno od prvih udžbenika psihologije ličnosti. ${ }^{3}$ Obzirom da postoje različiti pristupi u proučavanju ličnosti kao što su psihoanalitički, psihobiološki i psiholeksički pristup u proučavanju ličnosti, u ovom radu govoriti će se posebno o Petofaktorskom modelu ličnosti. Petofaktorski model sadrži dimenziju ekstraverzije, prijatnosti, savjesnosti, neuroticizma i otvorenosti ka iskustvu.

Ekstraverzija kao dimenzija ličnosti se odlikuje upadljivom orijenacijom ka vanjskom okruženju. Osobe sa visokim skorovima na ovoj dimenziji imaju mnogo entuzijazma, okrenute su ka akciji, privlače pažnju i pričljive su. Nasuprot tome introverti ne vode aktivan, bogat i energičan život. Oni ispoljavaju tendenciju da budu tihi, zatvoreni, promišljeni i odvojeni od socijalnog svijeta. Prijatnost je dimenzija koja uključuje osobine kao što su saosjećajnost, ljubaznost i odanost. Ona održava individualne razlike u saradljivosti sa drugim ljudima. Prijatne osobe vole da budu u društvu ljudi. Osobe sa niskom skorovima na ovoj dimenziji stavljaju vlastite interese iznad interesa drugih. Savjesnost obuhvata osobine kao što su sklonost planiranju, organizovanost i efikasnost. Savjesne osobe izbjegavaju nevolje i uspješne su u planskim i cilju usmjerenim aktivnostima. U ekstremnim slučajevima, osobe sa visokim skorom na savjesnosti mogu biti opsesivno pedantne ili radoholočari. S druge strane, nesavjesne individue mogu često biti nepouzdane $\mathrm{i}$ ispoljavati nedostatak ambicije i nesposobnost usmjeravanja na određenu aktivnost. Neuroticizam uključuje indikatore anksioznosti, napetosti i lošeg raspoloženja. Neuroticizam se odnosi na sklonost ka doživljavanju negativnih emocija. Osobe sa visokim skorom na neuroticizmu emocionalno reaguju na povode koji druge ljude ostavljaju ravnodušnim ili ih ne uznemiravaju previše. Osobe sa niskim skorom na ovoj dimenziji se ne

\footnotetext{
${ }^{3}$ Larsen, R. J. i Buss, D. M. (2005). Introduction to personality. In Personality psychology: Domains of knowledge about human nature (2nd ed., 1-23). Boston: McGraw-Hill.
} 
uznemiravaju lako i adekvatnije regulišu vlastitu emocionalnost. Otvorenost ka iskustvu obuhvata osobine kao što su imaginativnost i širok spektar interesovanja. Otvorene osobe su intelektualno radoznale, osjetljive na ljepotu i umjetnost. Osobe sa niskim skorovima na ovoj dimenziji imaju uska, uobičajena interesovanja. Mogu ispoljavati sumnju i skepticizam prema naučnim i umjetničkim dostignućima. ${ }^{4}$ Rezultati istraživanja podržavaju pretpostavku da neke dimenzije ličnosti disponiraju pojedinca za upotrebu pojedinih strategija suočavanja sa stresnim događajima $i$ to $u$ različitim kulturama. Smederevac i Mitrović ${ }^{5}$ ističu da su neke crte ličnosti zaštitni faktori stresnih događaja, kao npr. konstruktivno mišljenje, otpornost, samoefiasnost, osjećaj koherentnosti.

\section{Strategije suočavanja sa stresom}

Stres $^{6}$ je u savremenom svijetu prepoznat kao važan faktor koji utiče na zdravlje. Moguće ga je konceptualizirati na tri načina: podražajni pristup definira stres kao karakteristiku podražaja u čovjekovoj okolini; medicinsko-fiziološki pristup promatra stres kao reakciju organizma na okolinske podražaje i psihološki pristup konceptualizira stres kao interakciju pojedinca i okoline. ${ }^{7}$ Strategije prevladavanja predstavljaju opšte dispozicije za određeni način ponašanja u različitim okolnostima koje su prethodno procjenjene kao stresne, a koje u osnovi imaju slične karakteristike. Ostvaruju svoj uticaj na različite faze i aspekte stres procesa, kao i na kratkoročne i dugoročne efekte stresa. Brdar i Bakarčić ${ }^{8}$ navode da se uspješnost načina suočavanja određuje prema

\footnotetext{
${ }^{4}$ Smederevac, S. i Mitrović, D. (2009). Ličnost - metodi i modeli. Beograd: Centar za primenjenu psihologiju.

${ }^{5}$ Lazarus, R. S.i Folkman, S. (2004). Stres, procjena i suočavanje. Jastrebarsko: Naklada slap.

${ }^{6}$ Stres je obrazac emocionalnih i fizičkih reakcija koje prati subjektivan osjećaj preopterećenosti i koje nastaju kao reakcija na određene događaje.

${ }^{7}$ Hudek - Knežević, J. i Kardum, I. (2006). Stres i tjelesno zdravlje. Jastrebarsko: Naklada slap.

${ }^{8}$ Brdar, I. i Bakarčić, S. (2006). Suočavanje s neuspjehom u školi: koliko su važni emocionalna kompetentnost, osobine ličnosti $i$ ciljna orijentacija u učenju? Rijeka: Filozofski fakultet Sveučilišta u Rijeci i Zavod za kliničku, zdravstvenu i organizacijsku psihologiju.
} 
postizanju neposrednog smanjenja intenziteta stresa kao i u doprinosu dugoročnim posljedicama. Suočavanje sa stresom najčešće se dijeli prema fokusu suočavanja na problem i emocije usmjereno suočavanje. Njihova je funkcija rješavanje problema koji je izazvao stres, odnosno umanjivanje ili regulacija emocionalnog stanja koje izaziva stresor ${ }^{9}$.

Endler i Parker zastupaju shvatanje da postoje tri dimenzije suočavanja: suočavanje usmjereno na problem, suočavanje usmjereno na emocije $\mathrm{i}$ suočavanje usmjereno na izbjegavanje. Suočavanje sa stresom predstavlja nastojanje organizma da odgovori fizčkim, socijalnim i psihološkim zahtjevima sa dvije glavne funkcije: usmjerenost na emocije i usmjerenost na problem. U većini stresnih situacija suočavanje usmjereno na problem praćeno je sa suočavanjem usmjerenim na emocije. Treći stil suočavanja sa stresom je suočavanje izbjegavanjem. Za izbjegavanje kao stil suočavanja može se reći da je suprotnost čvrstoći, jednom od najčešće primjenjivanih konstrukata na području suočavanja sa stresom. ${ }^{10}$

Modeli otpornosti na stres mogu se podijeliti u dvije široke kategorije: modeli koji opisuju set faktora što utiču na otpornost na stres i proces po kojem ti faktori funkcioniraju i modele koji podrazumijevaju da stepen slaganja između osobe i okoline određuje kvalitetu otpora prema stresu. Kobasa predlaže teoriju u kojoj otpornost (eng. hardiness) utiče na interpretaciju stresnih životnih događaja $u$ određenju tzv. transformacijskog suočavanja. Autorica je izvela koncept otpornosti iz fenomenološke perspektive koja naglašava holistički pogled na svijet, s tri komponente - osjećaja privrženosti, kontrole i izazova. Transformacijsko suočavanje se odnosi na prijevod stresnih događaja $u$ poruke koje su značajne za pojedinca i istovremeno facilitiraju aktivno reagiranje. Lazarus i Folkman ${ }^{11}$ predlažu tzv. transakcijski model kako bi objasnili otpornost na stres. U tom modelu istaknuta su dva glavna procesa: procjena i suočavanje. Procjena je definirana kao proces kategoriziranja susreta i njegovih raznolikih aspekata, s uviđanjem

\footnotetext{
${ }^{9}$ Stresor je svaki fizički, psihički ili socijalni poticaj koji može izazvati stres.

${ }^{10}$ Hudek - Knežević, J. i Kardum, I. (2006). Stres i tjelesno zdravlje. Jastrebarsko: Naklada slap.

11 Lazarus, R. S.i Folkman, S. (2004). Stres, procjena i suočavanje. Jastrebarsko: Naklada slap.
} 
njegove značajnosti za dobrobit pojedinca. Procjena može biti primarna i sekundarna. Primarna služi za kategoriziranje stepena prijetnje u susretu. Sekundarna procjena je pak evaluacija onoga što bi se moglo učiniti da se neutralizira prijetnja iz primarne procjene. ${ }^{12}$

\section{Karakteristike i priroda dimenzija ličnosti Petofaktorskog model}

Empirijski nalazi vezani uz vremensku stabilnost crta ličnosti operacionaliziranih kroz petofaktorski model upućuju na zaključak da je ličnost pojedinca relativno konzistentna kroz vrijeme. Viswesvaran i Ones proveli su metaanalizu stabilnosti skala Petofaktorskog upitnika ličnosti, a njihovi su rezultati pokazali da se koeficijenti kreću od 0.69 za ugodnost do 0.76 za ekstraverziju. Iz ovih kao i nekih drugih nalaza kao što su nalazi autora Schuerger, Zarrella i Hotz proizlazi da su ekstraverzija i neuroticizam najstabilnije crte, visoko su stabilne i savjesnost i otvorenost za iskustva, dok je najniže stabilnosti crta ugodnosti. Isti autori proveli su i metaanalizu pouzdanosti interne konzistencije skala petofaktorskog upitnika i dobili da se ona kreće od 0.73 za otvorenost, do 0.78 za ekstraverziju, neuroticizam i savjesnost. Stabilnost i promjene u dimenzijama ličnosti mogu se pratiti na tri razine: promjene na nivou populacije, tj. promjene koje svi doživljavaju od djetinstva do odrasle dobi, zatim grupne razlike, odnosno razlike koje svi doživljavamo od djetinstve do odrasle dobi i individualne razlike, tj. predviđanje kod koga će doći do promjena u dimenzijama ličnosti. ${ }^{13}$

Dimenzija ličnosti ekstraverzija se odnosi na pristup socijalnom svijetu. Ekstraverzija određuje broj međuljudskih odnosa sa kojima se osoba osjeća lagodno. Osobe koje postižu visoke rezultate na ovoj dimenziji karakteriše visoka uključenost $u$ vanjski svijet, sklonost da se uspostavljaju odnosi sa velikim brojem ljudi, preferencija za velike grupe i skupove, sklonost ka traženju uzbuđenja, ka doživljavanju pozitivnih emocija i optimizam. Osobe koje postižu niske rezultate na ovoj dimenziji se lagodnije osjećaju kada nisu okruženi velikim brojem

\footnotetext{
${ }^{12}$ Hobfoll, S. E. (1998). The ecology of stress. New York: Hemisphere Publising Corp.

13 Krapić, N., Ćoso, B. i Sušanj, Z. (2006). Crte ličnosti i stavovi prema radu $i$ organizaciji kao prediktori tjelesnih simptoma zaposlenika. Psihologijske teme. 15(1): 81-100.
} 
ljudi, rezervisani su, što ne znači da su nedruštveni, nezavisniji i umjereniji. Ovo ne znači da su stidljivi i depresivni. Introvertima je jednostavno potrebno manje stimulacije i zato samo preferiraju manje grupe ili samoću. Ekstraverzija je pored neuroticizma najbolje zasnovana dimenzija modela Velikih Pet. Pored toga, to je dimenzija koja je ovakva ista ili slična sadržana u velikom broju drugih modela ličnosti. $^{14}$

Dimenzija ličnosti prijatnost se odnosi na interpersonalnu orijentaciju. Karakteristični pridjevi su ljubazan, povjerljiv, prijateljski, blag i slično. Suprotan pol ove dimenzije je antagonizam, a uključuje karakteristike poput nepovjerljivosti, tvrdoglavosti, grubosti i nekooperativnosti. Prijatnost se obično smatra poželjnom i adaptivnom, ali i antagonizam je u određenoj mjeri nužan za svakodnevno funkcioniranje. Osobe koje postižu visoke skorove na dimenziji prijatnosti su bazično altruistične, simpatišu i saosjećaju sa drugima, osjećaju potrebu da im pomognu. Imaju pozitivna vjerovanja o ljudima, vjeruju da su ljudi iskreni, prijateljski nastrojeni, dobri i također spremni da im pomognu. Osobe sa niskim skorovima na ovoj dimenziji stavljaju lične interese prije svih ostalih i generalno nisu skloni da se brinu za dobrobit drugih. Njihova sumnja u motive drugih ih može učiniti sumnjičavima, neprijateljski nastrojenima i nesaradljivima. Ljudi sa visokim skorovima na ovoj dimenziji su obično omiljeniji u društvu, što ih čini odgovarajućim za određena zanimanja. Ali, s druge strane osobe koje postižu niske skorove na ovoj dimenziji su superiorne u situacijama kada treba donositi objektivne sudove. Osobe sa niskim skorovima na ovoj dimenziji mogu biti odlični naučnici, kritičari ili vojnici. $^{15}$

Savjesnost je dimenzija koja se odnosi na broj ciljeva na koji je neko usmjeren kao i samokontrolu, sistematičnost i istrajnost u njihovom ostvarivanju. Osobe sa visokim skorovima na ovoj dimenziji usmjerene su na nekoliko ciljeva i pokazuju samodisciplinu povezanu sa tim usmjerenjem. To su osobe snažne volje, skrupulozne, tačne i pouzdane.

\footnotetext{
${ }^{14}$ Smederevac, S. (2000). Istraživanje faktorske strukture ličnosti na osnovu leksičkih opisa ličnosti u srpskom jeziku. Doktorska disertacija, Novi Sad: Filozofski fakultet.

${ }^{15}$ Knežević, G., Radović, B. i Opačić, G. (1997). Evaluacija „Big Five“ modela ličnosti kroz analizu inventara ličnosti NEO PI-R. Psihologija. 30, 7-40.
} 
Osobe sa niskim skorovima na ovoj dimenziji teže da budu usmjerene na veći broj ciljeva kojima prisupaju površno, nesistematično i sa velikom dozom spontanosti. Ovakve osobe nisu amoralne, ali su moralni principi za njih daleko manje obavezujući, a daleko su i bezbrižnije kada su u pitanju ciljevi koje su usvojili. Dimenzija ličnosti neuroticizam predstavlja sklonost da se doživljavaju neprijatne i uznemirujuće emocije, sklonost uznemirenosti u mislima i akcijama. Neuroticizam označava sklonost proživljavanju psihološkog stresa, te kognitivnim i bihevioralnim stilovima koji proizlaze iz te sklonosti. Osobe koje postižu visok rezultat na ovoj dimenziji su sklone iracionalnim idejama, slabije kontrolišu svoje impulse i imaju slabije kapacitete za prevladavanje stresnih situacija. Osobe koje postižu nizak rezultat na ovoj dimenziji odlikuje stabilnost, staloženost i sposobnost da se sa stresnim situacijama suoče bez pretjerane panične uznemirenosti. Neuroticizam je pored ekstraverzije najbolje zasnovana i „najsigurnija“ dimenzija modela Velikih Pet. Dimenzija ličnosti otvorenost ka iskustvu je faktor oko kojeg se autori najmanje slažu. Pristalice leksičkog pristupa ga nazivaju intelektom. Otvorenost ka iskustvu je dimenzija koja razlikuje maštovite, kreativne ljude od konvencionalnih ljudi koji stoje čvrsto na zemlji. Osobe koje postižu visoke skorove na ovoj dimenziji sklone su prihvatanju novih iskustava, ideja i stavova. Mnogo intenzivnije doživljavaju kako pozitivne, tako i negativne emocije u odnosu na ljude koji postižu niske skorove na ovoj dimenziji. Osobe koje postižu niske skorove na ovoj dimenziji su konvencionalne, konzervativnog izgleda i držanja, preferiraju poznato u odnosu na novo, emocionalne reakcije su im prigušene. ${ }^{16}$

\section{Doživljavanje stresne epizode i posljedice stresa}

\subsection{Doživljavanje stresne epizode}

Postoje tri načina na koja se može shvatiti i upotrebljavati pojam stresa: može se odnositi na unutarnje stanje organizma, vanjski događaj (,stresor") ili iskustvo koje proizlazi iz interakcije između osobe i okoline. Stres obuhvata fiziološke i emocionalne reakcije. Pretpostavka

\footnotetext{
${ }^{16}$ Knežević, G., Radović, B. i Opačić, G. (1997). Evaluacija „Big Five“ modela ličnosti kroz analizu inventara ličnosti NEO PI-R. Psihologija. 30, 7-40.
} 
jeste da stres ima negativne fiziološke efekte. Međutim, tačnije bi bilo percipirati uticaj stresa kao aktivacijski, što može biti ujedno pozitivno i negativno, ovisno o mnogobrojnim okolinskim i kontekstualnim faktorima. Stres može proizlaziti iz vanjskog okruženja. Struktura socijalnih uloga također može dovesti do situacija iz kojih proizlazi stres. Postoji i teorija o četiri vrste napora uvjetovanih socijalnim ulogama: preopterećenje (ukoliko imamo previše obaveza); interpersonalni konflikti unutar uloga; zatočeništvo unutar određene uloge (primjerice ne možemo prekinuti stresan posao zbog financijskih razloga) i uloge povezane s ambijentom (primjerice život u siromašnom okruženju). ${ }^{17}$ Uslovi sa kojima se pojedinci moraju nositi oblikuju granice njihovih reakcija. Neki određeni stresor rezultira setom svojstvenih reakcija, ali isključuje neke druge reakcije. Slično tome, reakcije koje mogu biti anticipirane $u$ odgovoru na neku stresnu situaciju su irelevantne u nekom drugom kontekstu. Na primjer, interpersonalni konflikt je relativno česta pojava u svakodnevnom životu, oblik je socijalne interakcije koju mnogi ljudi doživljavaju kao prijeteću, uznemirujuću, otežavajuću, ili jednostavno neugodnu. ${ }^{18}$ Percepcija stresa ovisi o tome koliko su opsežni zahtjevi okoline i količine resursa sa kojim se raspolaže prilikom suočavanja. Teoretski, pojedinac prvo prepoznaje da postoji problem, a potom određuje koje resurse mora steći kako bi se suočio s tim problemom. Stres nastaje zbog neravnoteže između zahtjeva okoline i pojedinčevih sposobnosti da se suoči s njima. ${ }^{19}$

\subsection{Posljedice stresa}

Postoje kratkoročne i dugoročne posljedice stresa. Kratkoročne posljedice se odnose na one stresne događaje koji su završeni, a ne na trajne situacije. Govoreći o takvim, kratkoročnim posljedicama, misli se na emotivne i fiziološke reakcije koje pojedinac u stresnoj situaciji

\footnotetext{
${ }^{17}$ Pearlin, L. I. (1989). The sociological study of stress. Journal of Health and Social Behavior, 30, $241-256$.

${ }^{18}$ Kaplan, H. B. (1996). Psychosocial stress: perspectives on structure, theory, lifecours and methods. San Diego: Academic Press.

${ }^{19}$ Lazarus, R. S. (1966). Psychological stress and the coping process. New York: McGraw - Hill Book Company.
} 
proživljava i na njegove lične procjene kvalitete ishoda. ${ }^{20}$ Kratkoročne posljedice s obzirom na kvalitetu mogu podijeliti na zadovoljavajuće i nezadovoljavajuće. Zadovoljavajuće posljedice ukazuju da je stresna situacija razriješena na način na koji odgovara pojedincu, a nezadovoljavajuće posljedice ukazuju da je situacija razriješena, ali ne na način koji odgovara pojedincu ili je nerazriješena i pogoršana. Dugoročne posljedice, zadovoljavajuće ili nezadovoljavajuće utiču na dugoročno funkcionisanje pojedinca u životu i društvu. ${ }^{21}$

\section{Strategije suočavanja sa stresom i životna razdoblja}

Pazina doživljenog stresa nije ista u svim životnim razdobljima. Od djetinjstva prema ranoj adolescenciji razina stresa raste, oko petnaeste godine dostiže maksimum i na toj razini ostaje kroz adolescenciju. Jedno od objašnjenja porasta razine doživljenog stresa u funkciji dobi je sve veći broj stresnih situacija kojima smo izloženi kroz život. Analize suočavanja u različitoj dobi pokazuju da je dob od petnaest godina tačka preokreta u upotrebi uspješnijih strategija. Stariji adolescenti su aktivniji, raspolažu većim brojem različitih strategija, a uz to imaju veću sposobnost razmatranja problema iz različitih perspektiva. Osim toga, sve bolje suočavanje sa stresom tokom rane i srednje adolescencije nesumnjivo djeluje na to koliko će se pojedinac dobro suočavati s novim stresorima koji se javljaju tokom kasne adolescencije i u prijelazu prema zreloj dobi. ${ }^{22}$

Strategije suočavanja su mnogo općenitija mjera suočavanja koja govori o procesima kroz različite stresne situacije kao i takve su bolji pokazatelji adaptacije. Stil suočavanja je u skladu sa ličnim vrijednostima, uvjerenjima i ciljevima pojedinaca, premda to ne znači

20 Pregrad, J. (1996). Stres, trauma, oporavak: udžbenik programa. Osnove psihosocijalne traume i oporavka. Zagreb: Društvo za psihološku pomoć.

${ }^{21}$ Folkman, S., Lazarus, R. S., Dunkel - Schetter, C., DeLongis, A. i Gruen, R. J. (1986). Dynamics of a Stressful Encounter: Cognitive Appraisal, Coping, and Encounter Outcomes. Journal of Personality and Social Psychology, 50, 992-1003 Jastrebarsko: Naklada slap.

${ }^{22}$ Brdar, I. i Bakarčić, S. (2006). Suočavanje s neuspjehom u školi: koliko su važni emocionalna kompetentnost, osobine ličnosti i ciljna orijentacija u učenju? Rijeka: Filozofski fakultet Sveučilišta u Rijeci i Zavod za kliničku, zdravstvenu i organizacijsku psihologiju. 
da postoji konzistentnost u korištenju određenih strategija suočavanja $u$ različitim stresnim situacijama i u funkciji vremena. Kada se radi o djeci i adolescentima istraživanja na ovom području su malobrojna. Utvrđeno je da djetetov dispozicijski stil suočavanja ima mnogo značajniju ulogu u odabiru načina odgovora u specifičnoj stresnoj situaciji, nego što je to slučaj kod odraslih. Strategija koja će se u nekoj situaciji pokazati kao najefikasnije i najbolje rješenje, ne mora dati isti rezultat u sličnoj situaciji u drugim okolnostima. Osoba sa razvijenim strategijama je mnogo senzitivnija na promjene u sebi i oko sebe i može bolje i efikasnije odgovarati na različite stresne situacije. ${ }^{23}$

\section{Strategije suočavanje sa stresom i dimenzije ličnosti (prikaz ranijih istraživanja)}

U nastavku ćemo prikazati nalaze, rezultate dosadašnjih istraživanja koja su ispitivala povezanost dimenzija ličnosti Petofaktorkog modela sa strategijama suočavanja sa stresom.

Rezultati dosadašnjih istraživanja pokazuju da su neke dimenzije ličnosti važni prediktori strategija suočavanja koje pojedinci koriste u stresnim situacijama. ${ }^{24}$ Osobe koje su visoko na dimenziji ekstraverzije imaju sklonost doživljavati ugodne emocije i biti socijalni, topli, veseli, energični $i$ asertivni. ${ }^{25}$ Istraživanja pokazuju da ekstraverti više pribjegavaju problemu usmjerenom suočavanju sa stresom i usvajaju manje neadaptivnih, a više adaptivnih formi emocijama usmjerenog suočavanja, poput traženja potpore, pozitivnog razmišljanja ili reinterpretacije, supstitucije i suzdržavanja. ${ }^{26}$ Ekstraverzija kao dimenzija ličnosti je bolji prediktor kod aktivnog (upornost, racionalnost), a neuroticizam kod pasivnog (izbjegavanje,

\footnotetext{
${ }^{23}$ Vulić - Prtorić, A. (1997) Koncept suočavanja sa stresom kod djece i adolescenata i načini njegova mjerenja. Pregledni članak. Zadar: Filozofski fakultet.

${ }^{24}$ Mikšaj-Todorović, Lj. i Novak, T. (2008). Istraživanje emocionalnog dobrostanja i sagorijavanja na poslu zatvorskog osoblja. Kriminologija i socijalna integracija. Vol. 16, Br. 1, 45-60.

${ }^{25}$ Lee-Baggley, D., Preece, M. i DeLongis, A. (2005). Coping with interpersonal stress. Role of big Five traits. Journal of Personality, 73, 1141-1180.

26 McCrae, R. R. i Costa, P. T. Jr. (1986). Personality, coping, and coping effectiveness in an adult sample. Journal of Personality, 54, 385-405.
} 
neprijateljstvo i pasivnost) načina suočavanja sa stresom. $^{27}$ Esktraverzija se povezuje sa aktivnim, socijalnim i optimističnim pristupom stresnom događaju i višom percepcijom kontrole. ${ }^{28}$ Neka istraživanja ukazuju na povezanost ekstraverzije sa suočavanjem usmjerenim na problem koji uključuje racionalnu akciju, pozitivno mišljenje, zamjenu i obuzdavanje suočavanja). ${ }^{29} \mathrm{~S}$ druge strane, neka istraživanja su pokazala kako ekstraverti također koriste $i$ adaptivne forme emocijama usmjerenog suočavanja. ${ }^{30}$ Isto tako, neka istraživanja su pokazala kako je ekstraverzija najviše povezana sa traženjem socijalne podrške, odnosno da je značajan prediktor suočavanja putem emocija. ${ }^{31}$ Većina dosadašnjih istraživanja na odraslim ispitanicima $i$ adolescentima pokazala su da je ekstraverzija pozitivno povezana sa strategijom suočavanja usmjerenom na problem i na emocije. ${ }^{32}$

Osobe sa visokim skorom na dimenziji neuroticizma češće se služe izbjegavanjem i samookrivljavanjem od osoba s niskim skorom na dimenziji neuroticizma u iritantnim situacijama koje izazivaju ljutnju. ${ }^{33}$ Neuroticizam u manjoj mjeri povezan sa strategijom suočavanja koja podrazumijeva usmjerenost na problem i traženje socijalne podrške, a $\mathrm{u}$ većoj sa korištenjem maštanja i izbjegavanja). ${ }^{34}$ Neuroticizm je $u$

${ }^{27}$ Costa, P. T. i McCrae, R. R. (1992). The revised NEO Personality Inventory (NEO$P I-R)$ and NEO Five Factor Inventory (NEO-FFI) professional manual. Odessa, FL: Psychological Assessment Resources.

${ }^{28}$ Hudek - Knežević, J. i Kardum, I. (2006). Stres i tjelesno zdravlje. Jastrebarsko: Naklada slap.

${ }^{29}$ Božičević, V., Brlas, S. i Gulin, M. (2010). Psihologija u zaštiti mentalnog zdravlja. Virovitica: Grafiti Becker.

${ }^{30}$ Čabarkapa, M., Korica, V. i Rodjenkov, S. (2011). Povezanost osobina ličnosti sa doživljajem profesionalnog stresa kod vojnog letačkog osoblja. Vojnosanitetski pregled. Vol. 68, Br. 2, 143-149.

${ }^{31}$ Hudek - Knežević, J. i Kardum, I. (2006). Stres i tjelesno zdravlje. Jastrebarsko: Naklada slap.

${ }^{32}$ Lazarus, R. S.i Folkman, S. (2004). Stres, procjena i suočavanje. Jastrebarsko: Naklada slap.

${ }^{33}$ Atkinson, M. i Vialto, C. (1994). Neuroticism and coping with anger: The transsituational consistency of coping responses, Personality and Individual Differences. 17, 6, 769-782.

${ }^{34}$ Arambašić, L. (1994). Provjera nekih postavki Lazarusovog modela stresa i načina suočavanja sa stresom. Doktorska disertacija. Zagreb: Filozofski fakultet. 
visokoj korelaciji sa skalom na emocije usmjerenog suočavanja iz multidimenzionalnog inventara suočavanja. ${ }^{35}$ Neuroticizam se povezuje sa slabijim korištenjem efikasnijih strategija poput problemu usmjerenog suočavanja i češćim korištenjem suočavanja putem izbjegavanja. ${ }^{36}$

Osobe čiji su rezultati visoko na dimenziji otvorenosti često su kreativni, imaginativni, znatiželjni, „filozofski otvorenog uma“ i fleksibilni u svom razmišljanju. Skloniji su doživjeti raznolikiji spektar emocija, s obzirom da imaju široke interese, preferiraju raznovrsnost te se drže nekonvencionalnih vrijednosti. ${ }^{37}$ Istraživanja pokazuju da su otvoreniji ljudi skloni koristiti humor u suočavanju sa stresom, koristiti pozitivnu ponovnu procjenu događaja i planirati svoju strategiju suočavanja.

Pojedinci s visokim rezultatom na dimenziji ugodnosti imaju tendenciju biti altruistični, pomirljivi, povjerljivi i spremni pomoći. Manje su skloni usvojiti emocijama usmjerene strategije. Umjesto toga, više koriste pozitivnu ponovnu procjenu i planirano rješavanje problema. ${ }^{38}$ Nalazi u vezi dimenzije ugodnosti i suočavanja sa stresom su generalno poprilično skromni. Jedno od rijetkih istraživanja koje je ispitivalo ovu dimenziju ličnosti u kontekstu svakodnevnih procesa, pokazalo je kako ugodnost nije povezana s korištenjem strategija suočavanja. ${ }^{39}$ Osobe koje ostvaruju visoke rezultate na dimenziji savjesnosti su organizirane, pouzdane, marljive, odlučne i samodisciplinirane. Takve su osobe manje sklone pribjeći izbjegavanju i emocijama usmjerenim strategijama. S druge strane postoje rezultati koji potvrđuju da je

35 Krapić, N., Ćoso, B. i Sušanj, Z. (2006). Crte ličnosti i stavovi prema radu $i$ organizaciji kao prediktori tjelesnih simptoma zaposlenika. Psihologijske teme. 15(1): 81-100.

${ }^{36}$ Hudek - Knežević, J. i Kardum, I. (2006). Stres i tjelesno zdravlje. Jastrebarsko: Naklada slap.

${ }^{37}$ Lee-Baggley, D., Preece, M. i DeLongis, A. (2005). Coping with interpersonal stress. Role of big Five traits. Journal of Personality, 73, 1141-1180.

${ }^{38}$ Watson, D. i Hubbard, B. (1996). Adaptational style and dispositional structure: Coping in the context of the five-factor model. Journal of Personality, 64, 737-774.

${ }^{39}$ David, J. P. i Suls, J. (1999). Coping efforts in daily life: Role of Big Five traits and problems appraisals. Journal of Personality, 67, 265-294. 
savjesnost povezana s manjim oslanjanjem na religiju, a nisu dobili nikakvu povezanost sa strategijama suočavanja. ${ }^{40}$

\section{Zaključak}

U radu su predstavljene strategije ili modeli suočavanja sa stresom i dimenzije Petofaktorskog modela ličnosti (ekstraverzija, prijatnost, savjesnost, neuroticizam i otvorenost ka iskustvu). Rezultati provedenih istraživanja, nalaza koji su prikazani u radu govore o tome da su neke dimenzije ličnosti važni prediktori strategija suočavanja sa stresom koje pojedinci koriste $\mathrm{u}$ doređenim stresnim situacijama. Ekstraverti uglavnom koriste strategiju suočavanja koja je usmjerena na problem i na emocije. U različitim istraživanjima je dokazano da je neuroticizam uglavnom povezan sa izbjegavanjem i samookrivljavanjem, odnosno neuroticizam se povezuje sa slabijim korištenjem efikasnijih strategija poput problemu usmjerenog suočavanja i češćim korištenjem suočavanja putem izbjegavanja. Otvoreniji ljudi su skloni koristiti humor u suočavanju sa stresom i koristiti pozitivnu ponovnu procjenu događaja. Za takve osobe se veže i to da planiraju svoju strategiju suočavanja. Pojedinci s visokim rezultatom na dimenziji ugodnosti manje su skloni usvojiti emocijama usmjerene strategije. Umjesto toga, više koriste pozitivnu ponovnu procjenu i planirano rješavanje problema. Osobe koje ostvaruju visoke rezultate na dimenziji savjesnosti su manje sklone pribjeći izbjegavanju, te emocijama usmjerenim strategijama.

U ovom radu govorili smo o konstruktima koji su više predmet istraživanja u svijetu, nego u našoj sredini. U svijetu, radovi $\mathrm{i}$ istraživanja na ovu i slične teme su brojnija i njihovi rezultati su značajni. Implikacije ovog rada mogu predstavljati odrednice za daljnja ispitivanja odnosa strategija suočavanja sa stresom i dimenzijama ličnosti ili ispitivanja uloge strategija suočavanja sa stresom u održavanju boljeg mentalnog zdravlja. Budući istraživački radovi ovih konstrukata mogu dati nove smjernice i načine za poboljšanje kvalitete života i razvijanje boljih strategija suočavanja sa stresom.

${ }^{40}$ Lee-Baggley, D., Preece, M. i DeLongis, A. (2005). Coping with interpersonal stress. Role of big Five traits. Journal of Personality, 73, 1141-1180. 


\section{Literatura}

1. Arambašić, L. (1994). Provjera nekih postavki Lazarusovog modela stresa i načina suočavanja sa stresom. Doktorska disertacija. Zagreb: Filozofski fakultet.

2. Atkinson, M. i Vialto, C. (1994). Neuroticism and coping with anger: The trans-situational consistency of coping responses, Personality and Individual Differences. 17, 6, 769-782.

3. Božičević, V., Brlas, S. i Gulin, M. (2010). Psihologija u zaštiti mentalnog zdravlja. Virovitica: Grafiti Becker.

4. Brdar, I. i Bakarčić, S. (2006). Suočavanje s neuspjehom u školi: koliko su važni emocionalna kompetentnost, osobine ličnosti i ciljna orijentacija u učenju? Rijeka: Filozofski fakultet Sveučilišta u Rijeci i Zavod za kliničku, zdravstvenu i organizacijsku psihologiju.

5. Costa, P. T. i McCrae, R. R. (1992). The revised NEO Personality Inventory (NEO-PI-R) and NEO Five Factor Inventory (NEO-FFI) professional manual. Odessa, FL: Psychological Assessment Resources.

6. Čabarkapa, M., Korica, V. i Rodjenkov, S. (2011). Povezanost osobina ličnosti sa doživljajem profesionalnog stresa kod vojnog letačkog osoblja. Vojnosanitetski pregled. Vol. 68, Br. 2, 143-149.

7. David, J. P. i Suls, J. (1999). Coping efforts in daily life: Role of Big Five traits and problems appraisals. Journal of Personality, 67, 265294.

8. Davison, G. C. i Neal, J. M. (1999). Psihologija abnormalnog doživljavanja i ponašanja. Jastrebarsko: Naklada slap.

9. Endler, N. S. i Parker, J. D. A. (1990). The analysis of a construct that does not exist: Misunderstanding the multidimensional nature of trait anxiety, Educational and Psychological Measurement. 50. 265-271.

10. Folkman, S., Lazarus, R. S., Dunkel - Schetter, C., DeLongis, A. i Gruen, R. J. (1986). Dynamics of a Stressful Encounter: Cognitive Appraisal, Coping, and Encounter Outcomes. Journal of Personality and Social Psychology, 50, 992-1003 Jastrebarsko: Naklada slap.

11. Hobfoll, S. E. (1998). The ecology of stress. New York: Hemisphere Publising Corp.

12. Hudek - Knežević, J. i sar. (2009). Organizacijski stres i stavovi prema radu kao prediktori zdravstvenih ishoda. Prospektivno istraživanje. Društvena istraživanja. Vol.18, Br.1-2, 129-149.

13. Hudek - Knežević, J. i Kardum, I. (2006). Stres i tjelesno zdravlje. Jastrebarsko: Naklada slap. 
14. Kaplan, H. B. (1996). Psychosocial stress: perspectives on structure, theory, life - cours and methods. San Diego: Academic Press.

15. Knežević, G., Radović, B. i Opačić, G. (1997). Evaluacija „Big Five““ modela ličnosti kroz analizu inventara ličnosti NEO PI-R. Psihologija. 30, 7-40.

16. Krapić, N., Ćoso, B. i Sušanj, Z. (2006). Crte ličnosti i stavovi prema radu i organizaciji kao prediktori tjelesnih simptoma zaposlenika. Psihologijske teme. 15(1): 81-100.

17. Larsen, R. J. i Buss, D. M. (2005). Introduction to personality. In Personality psychology: Domains of knowledge about human nature (2nd ed., 1-23). Boston: McGraw-Hill.

18. Lazarus, R. S. (1966). Psychological stress and the coping process. New York: McGraw - Hill Book Company.

19. Lazarus, R. S.i Folkman, S. (2004). Stres, procjena i suočavanje. Jastrebarsko: Naklada slap.

20. Lee-Baggley, D., Preece, M. i DeLongis, A. (2005). Coping with interpersonal stress. Role of big Five traits. Journal of Personality, 73, 1141-1180.

21. McCrae, R. R. i Costa, P. T. Jr. (1986). Personality, coping, and coping effectiveness in an adult sample. Journal of Personality, 54, 385-405.

22. Mikšaj-Todorović, Lj. i Novak, T. (2008). Istraživanje emocionalnog dobrostanja i sagorijavanja na poslu zatvorskog osoblja. Kriminologija i socijalna integracija. Vol. 16, Br. 1, 45-60.

23. Pearlin, L. I. (1989). The sociological study of stress. Journal of Health and Social Behavior, 30, $241-256$.

24. Pregrad, J. (1996). Stres, trauma, oporavak: udžbenik programa. Osnove psihosocijalne traume i oporavka. Zagreb: Društvo za psihološku pomoć.

25. Smederevac, S. i Mitrović, D. (2009). Ličnost - metodi i modeli. Beograd: Centar za primenjenu psihologiju.

26. Smederevac, S. (2000). Istraživanje faktorske strukture ličnosti na osnovu leksičkih opisa ličnosti u srpskom jeziku. Doktorska disertacija, Novi Sad: Filozofski fakultet.

27. Vulić - Prtorić, A. (1997) Koncept suočavanja sa stresom kod djece i adolescenata i načini njegova mjerenja. Pregledni članak. Zadar: Filozofski fakultet. 
28. Watson, D. i Hubbard, B. (1996). Adaptational style and dispositional structure: Coping in the context of the five-factor model. Journal of Personality, 64, 737-774. 


\section{Arijana Midžić, B.A.}

University of Bihac

Islamic Pedagogical Faculty

arijana_91@windowslive.com

Original scientific article

\section{STRATEGIES FOR STRENGTH AND DIMENSION OF PERSONALITY}

\section{ABSTRACT}

Stress as a form of emotional and physical reactions that follows the feeling of overload and which arise as a reaction to certain events is common in people's lives. It is a significant factor that can adversely affect the day-to-day functioning of people and the quality of their relationships with others. People experience stress related to their everyday tasks. Previous research has shown that personality dimensions are significantly associated with strategies of stress management, and lately emphasizes the importance of a situation that affects the experience of stress in interaction with personality dimensions. In this paper, a relationship is developed between the strategies of dealing with stress and personality dimensions of the Fivefactory model (extraversion, pleasantness, conscientiousness, neuroticism and openness to experience). There are different models/strategies of dealing with stress, such as: focusing on emotions, problem-solving and the third strategy for coping with stress is avoidance, then models describing a set of factors that affect stress resistance and the process by which these factors function and models which implies that the degree of agreement between the person and the environment determines the quality of resistance to stress, the theory in which hardness influences the interpretation of stressful life events in determining the transformation confrontation and transaction model.

Keywords: stress, strategies of coping with stress, personality, personality dimensions. 


$$
\begin{aligned}
& \text { آريانة ميحيتش } \\
& \text { جامعاة بيهاتش } \\
& \text { كلية التربية الإسلامية } \\
& \text { ari_jana_91@windowslive.com }
\end{aligned}
$$

استر اتيجيات لمواجهة الضغط النفسي و أبعادُ الشخصية

\section{الخلاصية}

الضغط النفسي كشكل من أشكال ردود الفعل العاطفية والجسدية التي تتبع الشعور بالإجهاد والتي تنشأ كرد فعل لأحداث معينة هو أمر شائع في حياة الناس. إنه عامل

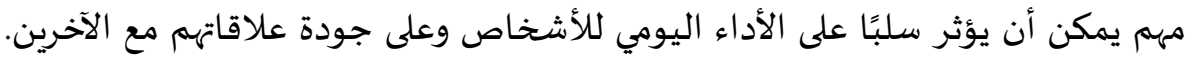

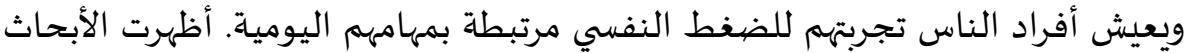

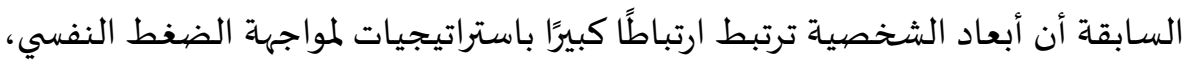

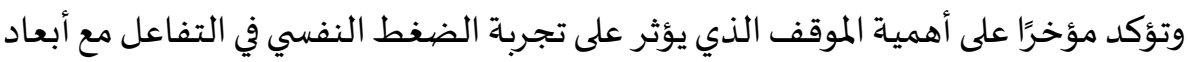

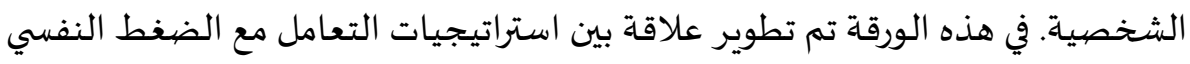

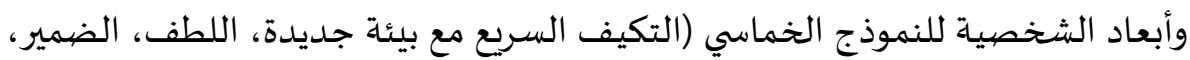
العصبية والانفتاح على التجربة).

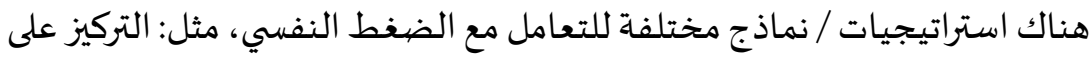

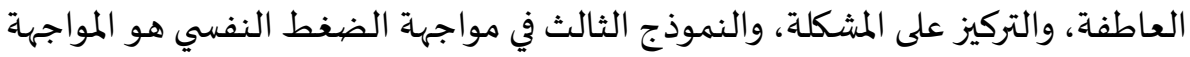
بالتجنب. ثم النماذج التي تصف مجموعة من العوامل التي تؤثر على مقاومة الضغط فئيط

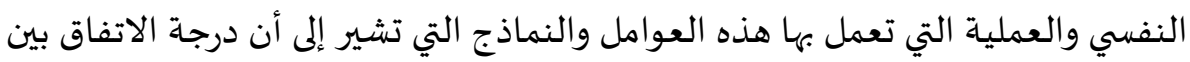

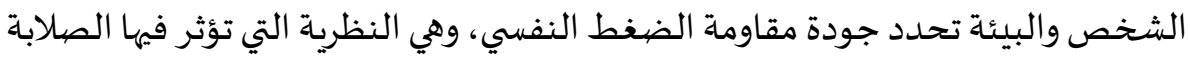
على تفسير أحداث الحياة المجهدة في تحديد ما يسمى: المواجهة التحويلية ونموذج الصفيقة.

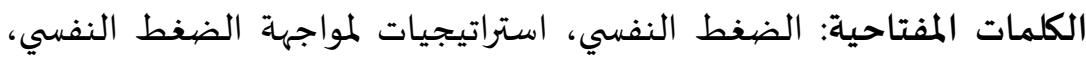

